\title{
Isolation of eight microsatellites loci from the saddled bream, Oblada melanura and cross-species amplification in two sea bream species of the genus Diplodus
}

\author{
S. Roques $\&$ J. A. Galarza $₫$ E. Macpherson $\downarrow$ \\ G. F. Turner $\downarrow$ J. Carreras-Carbonell $\downarrow$ C. Rico
}

\begin{abstract}
We have developed eight new microsatellite markers for the saddled bream (Oblada melanura) from an enriched genome library protocol. All these loci are polymorphic, with mean allelic diversity of 14.75 (range 3-22), and expected and observed heterozygosities from 0.233 to 0.918 and 0.212 to 0.913 , respectively. Cross-species tests in two close relatives of the genus Diplodus (D. sargus and D. vulgaris) revealed successful amplifications at 6 out of 8 loci, with means allele number of 6.67 (range 4-10) and 6.50 (range 4-10), respectively. These results are consistent with the close phylogenetic relationships between the three species, indicating this set of primers might proved useful for studying the levels of genetic diversity and population differentiation in these three species and in other phylogenetically close species of the genus Diplodus and Sparus.
\end{abstract}

Keywords Microsatellite - Oblada melanura .

Diplodus · Sea breams

S. Roques $(\boldsymbol{\&}) \cdot$ C. Rico

Estació n Biológica Doñ ana (CSIC), Av. Ma. Luisa S/N, 41013 Sevilla, Spain

e-mail: severine@ebd.csic.es

J. A. Galarza · G. F. Turner

Department of Biological Sciences, University of Hull, Hull HU6 7RX, UK

E. Macpherson · J. Carreras-Carbonell

Centre d'Estudis Avanç ats de Blanes (CSIC),

Carrer d'accés a la Cala Sant Francesc, núm.14,

17300 Blanes, Catalunya, Spain
The saddled bream, Oblada melanura, belongs to the Sparidae family, which includes commercially important species and has also recently gained considerable importance for aquaculture throughout the Mediterranean (Fischer et al. 1987). O. melanura is a diurnal schooling species, very common and abundant throughout the Mediterranean Sea and the Atlantic Ocean (Bay of Biscay and from the Strait of Gibraltar to Angola, Madeira, Cape Verde and the Canary Islands). It is considered a gregarious species and can be found over rocky bottoms and seagrass beds (Zostera and seaweeds) (Bauchot and Hureau 1990). They feed almost exclusively on small crustaceans and other zooplanktonic animals, which they graze from the substrata when juveniles, but when adults they feed mainly on vegetable matter. Apart from the feeding habits and the species distribution in the Adriatic region (Pallaoro et al. 1998, 2003, 2004), little information is available concerning its biology and population dynamics (Dufour et al. 1995; Lenfant and Olive 1998). Genetic analyses are scarce and have solely focused on resolving unclear phylogenetic relationships among sea bream species (Hanel and Sturmbauer 2000; Summerer et al. 2001). Here, we report the development and characterisation of 8 microsatellite loci for $\mathrm{O}$. melanura and present estimates of allelic variability of these loci and their cross-amplification in two close relatives, the white sea bream (Diplodus sargus) and the two-banded sea bream (Diplodus vulgaris). While the limited knowledge on the species' ecology can make a priori predictions about the population structure problematic, the characterisation of microsatellites variation in O. melanura and related taxa may give insights into the level of genetic diversity, the amount of gene flow and genetic structuring of these exploited marine 
species, that may be of great concern for their conservation.

Microsatellite markers were identified through the development of an enriched genomic library as described by Glenn et al. (2000). DNA extractions were performed from fin tissue and approximately $10 \mathrm{lg}$ of high molecular weight DNA was isolated by phenolchloroform extraction (Sambrook et al. 1989). Simultaneous restriction-ligation of genomic DNA was carried out using the RsaI restriction enzyme and double stranded linker-adapted primers according to Hamilton et al. (1999). Ligated DNA was enriched with a biotin-labelled probe mixture consisting of $(\mathrm{GT})_{10}$ and $(\mathrm{CT})_{10}$ at $10 \mathrm{1M}$ each. DNA fragments with repetitive sequences were then selectively captured by streptavidin-coated Dynabeads (Oxoid) and separated by a magnetic field. Enriched DNA was

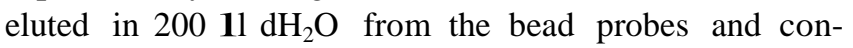
centrated by vacuum centrifugation to a final concentration of $\sim 100 \mathrm{ng} / \mathbf{l l}$. DNA was then reamplified by polymerase chain reaction (PCR), purified and ligated into a cloning vector using pGEM-T Easy Vector II (Promega). A total of 65 positive clones were screened and checked for inserts using ABI PRISM BigDye Terminator Cycle kit (Applied Biosystems) and resolved on an ABI 3100 Genetic Analyser (Applied Biosystems). Primer pairs for 8 potentially usable microsatellite loci were designed using the software package OLIGO 6.4. Polymorphism was tested by multiplex PCR reactions performed in $20 \mathbf{1 l}$ total volume, which include $50 \mathrm{ng}$ of DNA, $2 \mathrm{mM}$ of $\mathrm{MgCl}_{2}$, $0.251 \mathrm{M}$ of each primer, $200 \mathrm{1M}$ dNTP's, 1- reaction buffer [75 mM Tris-Hcl, $\left.20 \mathrm{mM}\left(\mathrm{NH}_{4}\right)_{2} \mathrm{SO}_{4}\right]$ and 0.5 units Taq polymerase (BIOTAQ). Reaction conditions were as follows: an initial denaturation step of $5 \mathrm{~min}$ at $95^{\circ} \mathrm{C}$, eight cycles consisting of $45 \mathrm{~s}$ at $92^{\circ} \mathrm{C}, 45 \mathrm{~s}$ at $53^{\circ} \mathrm{C}$ annealing temperature, $45 \mathrm{~s}$ at $72^{\circ} \mathrm{C}$ followed by an additional 24 cycles consisting of $30 \mathrm{~s}$ at $92^{\circ} \mathrm{C}, 30 \mathrm{~s}$ at $55^{\circ} \mathrm{C}$ annealing temperature, $30 \mathrm{~s}$ at $72^{\circ} \mathrm{C}$. Microsatellite variability was assessed in 48 individuals from the western Mediterranean coast (Tarifa). Individuals were genotyped by assessing allele size on an ABI 3100 Genetic Analyser (Applied Biosystems) using forward primers labelled with FAM (Sigma) and NED, PET and VIC (Applied Biosystems). Allele scoring was carried out using GENEMAPPER software version 3.5 (Applied Biosystems). Expected and observed values for heterozygosity, number of alleles per locus, allele size range as well as deviations from Hardy-Weinberg expectations (HWE) and linkage disequilibrium between pairs of loci were estimated using GENETIX version 4.05 (Belkhir et al. 2004). Significance was assessed using permutation procedures. All loci were

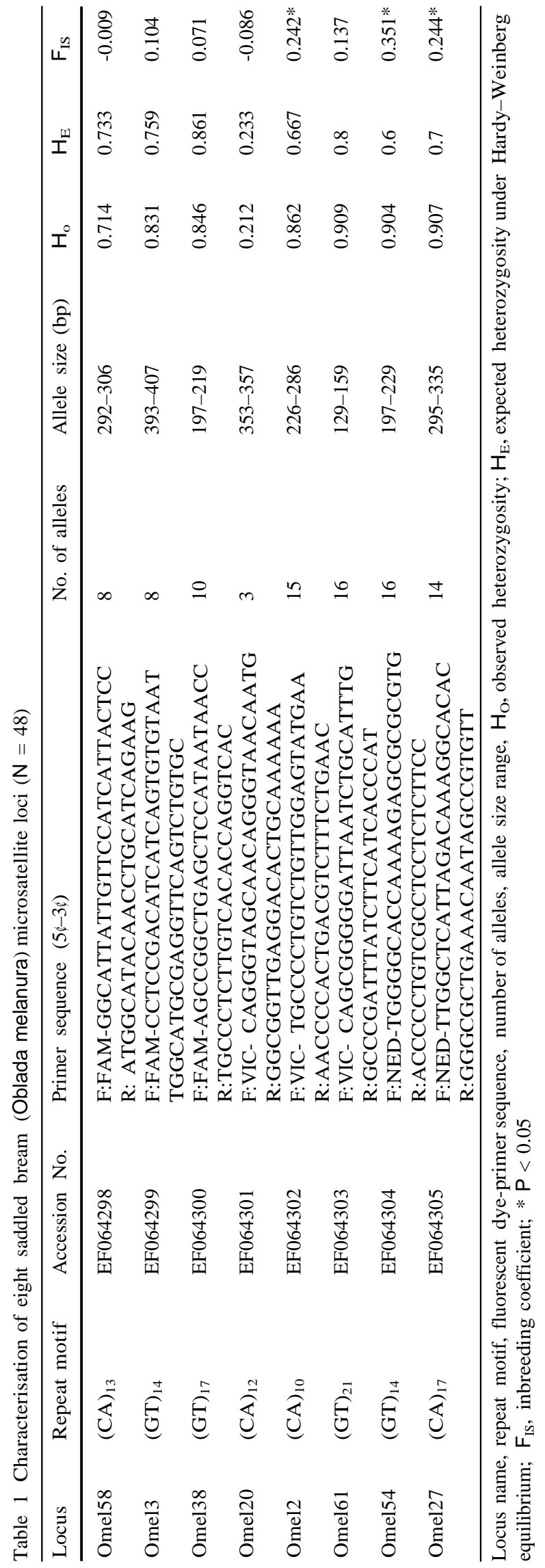


Table 2 Cross species amplification of 8 microsatellite loci from the saddled bream (Oblada melanura) in the white sea bream (Diplodus sargus) and the the two-banded sea bream (Diplodus vulgaris)

\begin{tabular}{llllll}
\hline Locus & \multicolumn{2}{l}{ D. sargus $(\mathrm{n}=7)$} & & \multicolumn{2}{c}{ D. vulgaris $(\mathrm{n}=8)$} \\
\cline { 2 - 3 } & na & Range & & na & Range \\
\hline Omel58 & 4 & $288-296$ & & 4 & $290-310$ \\
Omel3 & na & & na & \\
Omel38 & 9 & $193-235$ & & 6 & $183-199$ \\
Omel20 & 10 & $349-385$ & na & \\
Omel2 & 4 & $222-230$ & & 5 & $228-242$ \\
Omel61 & 8 & $139-161$ & 6 & $137-179$ \\
Omel54 & 5 & $193-207$ & & 8 & $221-261$ \\
Omel27 & na & & & 10 & $291-319$ \\
\hline
\end{tabular}

Locus name. number of alleles $\left(\mathrm{N}^{\mathrm{a}}\right)$. allele size range. na indicates non amplification

polymorphic; the total numbers of alleles per locus and heterozygosity estimates are listed in Table 1 . We found no evidence of linkage disequilibrium between locus pairs. Nonetheless, three loci (Omel2, Omel54 and Omel27) showed significant deviation from HWE, both showing heterozygote deficit.

Cross-species amplification was examined in two closed relatives (D. sargus and D. vulgaris) using the same conditions detailed for $\mathrm{O}$. melanura. All except one locus (Omel3) amplify in both or one of the species. All loci are polymorphic in both species, with allele number ranging from four to ten, depending on species and locus (Table 2), consistent with the close phylogenetic relationships between the three species (Day 2002; De la Herran et al. 2001; Summerer et al. 2001). This set of markers can be useful for studying the genetic diversity, population differentiation and for the genetic monitoring of farm populations of these three species, and might even proved useful in other phylogenetically close species of the genus Diplodus and Sparus.

Acknowledgements This work was funded in part by the Mexican Council for Science and Technology CONACYT and Junta de Andalucia Ref. 2003X880_1. We are grateful to Dr Philippe Lenfant for providing the $\mathrm{D}$. sargus samples for crossspecies amplifications.

\section{References}

Bauchot ML, Hureau JC (1990) Sparidae. In: Quero JC, Hureau JC, Karrer C, Post A, Saldanha L (eds) Check-list of the fishes of the eastern tropical Atlantic (CLOFETA). JNICT, Lisbon; SEI, Paris; UNESCO, Paris, vol. 2, p 803, pp 790-812

Belkhir K, Borsa P, Chikhi L, Raufaste N, Bonhomme F (19962004) GENETIX 4.05, logiciel sous Windows TM pour la génétique des populations. Laboratoire Génome, Populations, Interactions, CNRS UMR 5000, Université de Montpellier II, Montpellier, France

Day JJ (2002) Phylogenetic relationships of the Sparidae (Teleostei: Percoidei) and implications for convergent trophic evolution. Biol J Linn Soc 76:269-301

De la Herran R, Rejon CR, Rejon MR, Garridos-Ramos MA (2001) The molecular phylogeny of the Sparidae (Pisces, Perciformes) based on two satellite DNA families. Heredity 87:691-697

Dufour V, Jouvenel JY, Galzin R (1995) Study of a Mediterranean reef fish assemblage. Comparisons of population distributions between depths in protected and unprotected areas over one decade. Aquat Liv Res 8:17-25

Fischer W, Schneider M, Bauchot ML (1987) Fiches FAO d'identification des espèces pour les besoins de la pêche. Mediterranée et Mer Noire (zone de peche 37). FAO, Rome

Glenn TC, Cary T, Dust M, Hauswaldt S, Prince K, Clifton R, Shute I (2000) Microsatellite isolation. http://www.uga.edu/ srel/DNA_Lab/protocols.htm

Hamilton MB, Pincus EL, Di Fiore A, Flesher RC (1999) Universal linker and ligation procedures for construction of genomic DNA libraries enriched for microsatellites. Biotechniques 27:500-507

Hanel R, Sturmbauer C (2000) Multiple recurrent evolution of trophic types in Northeastern Atlantic and Mediterranean seabreams (Sparidae, Percoidei). J Mol Evol 50:276-283

Lenfant P, Olive C (1998) Gradual changing of the diet of juveniles of the saddled sea bream (Oblada melanura, Sparidae) during the recruitment. Cybium 22:203-210

Pallaoro A, Cetinic P, Dulcic J, Jardas I, Kraljevic M (1998) Biological parameters of the saddled bream, Oblada melanura, in the eastern Adriatic. Fish Res 38:199-205

Pallaoro A, Santic M, Jardas I (2003) Feeding habits of the saddled bream, Oblada melanura (Sparidae), in the Adriatic Sea. Cybium 27:261-268

Pallaoro A, Santic M, Jardas I (2004) Diet composition of youngof-the-year saddled bream, Oblada melanura (Linnaeus, 1758) from the eastern central Adriatic Sea. J Appl Ichth 20:228-230

Sambrook J, Fritsch EF, Maniatis T (1989) Molecular cloning: a laboratory manual, 2nd edn. Cold Spring Harbor Laboratory Press, New York

Summerer M, Hanel R, Sturmbauer C (2001) Mitochondrial phylogeny and biogeographic affinities of sea breams of the genus Diplodus (Sparidae). J Fish Biol 59:1638-1652 